\title{
Kansainvälisyyskasvatus aikuiskasvatuksessa
}

\section{— kokemuksia ja kehittämismahdollisuuksia}

Ylinen, Seppo 1989. Kansainvälisyyskasvatus aikuiskasvatuksessa - kokemuksia ja kehittämismahdollisuuksia. Aikuiskasvatus 9, 3, 109-115. - Artikkelissa pohditaan, miksi kansainvälisyyskasvatus on tarpeellista tämän päivän maailmassa ja mitkä seikat täytyy ottaa huomioon sitä järjestettäessä. Tarkastelun lähtökohtana on Työväen Sivistysliiton piirissä harjoitettu kehitysyhteistyö ja siitä saadut kokemukset. Kirjoittajan mukaan opiskelijoille on luotava kansainvälisyyskasvatuksen yhteydessä tilaisuus testata omia käsityksiään ja kokemuksiaan sekä tarjota heille omakohtainen mahdollisuus osallistua itse kehitysyhteistyöhön. Opetuksessa tulee kiinnittää erityisesti huomiota motivointiin, toiminnallisuuteen, havainnollisuuteen ja toiminnan arviointiin. Ongelmana kansalaisjärjestöjen kansainvälisyyskasvatuksen kehittämisessä kirjoittaja pitää resurssien vähäisyyttä.

\section{Kansainvälisyyskasvatuksen lähtökohtia}

Unesco suositteli vuonna 1976 aikuiskasvatuksen tavoitteiksi mm. seuraavia asioita:

- edistää työtä rauhan, kansainvälisen ymmärtämyksen ja yhteistyön hyväksi

— kehittää kykyä ymmärtää ja arvioida nykyajan suuria ongelmia ja yhteiskunnallisia muutoksia sekä osallistua aktiivisesti yhteiskunnan kehitykseen päämääränä yhteiskunnallinen oikeudenmukaisuus

- edistää ihmisen ja hänen fyysisen ja kulttuuriympäristönsä suhteen tiedostamista ja lisätä halukkuutta parantaa ympäristöä sekä kunnioittaa ja suojella luontoa, yhteistä kulttuuriperintöä ja yhteistä omaisuutta

- herättää ymmärtämystä ja kunnioitusta tapojen ja kulttuurien moninaisuutta kohtaan sekä kansallisella että kansainvälisellä tasolla

- auttaa paremmin tiedostamaan ja toteuttamaan erilaisia yhteydenpidon ja solidaarisuuden muotoja perheen piirissä, paikallisella ja kansallisella tasolla, lähikansojen kesken ja maailmanlaajuisessa vuorovaikutuksessa.

Unescon suosituksesta voinee yleisluontoisesti johtaa kansainvälisyyskasvatuksen sisällöiksi maailmantuntemuksen, kehityskysymykset, kulttuurien tuntemuksen, ihmisoikeuksien opettamisen, rauhakasvatuksen sekä ympäristö- ja joukkotiedotuskasvatuksen.
Kun tavoitteena on sanan varsinaisessa mielessä kansalaiskasvatus kansainvälisistä kysymyksistä, aikuiskasvatusta ei voi rajata pelkästään eriytyneeseen aikuiskasvatukseen.

Eriytyneellä aikuiskasvatuksella on tarkoitettu 'eriytynein kasvatustavoittein ja opinto-ohjelmin organisoitua toimintaa aikuisten suunnitelmallisesti etenevän oppimisen edistämiseksi'. (Ks. Alanen 198 ).

Tarkoitan tällä sitä, että vaikka TSL:n tyyppisissä sivistysjärjestöissä oppimista tapahtuukin perinteisissä kerhoissa, kursseilla, luentotilaisuuksissa tai kulttuuritapahtumissa, myös tiedottein tai av-materiaalien avulla, silti tämän lisäksi on harjoitettava aikuisiin suuntautuvaa tarkoituksellisesti kasvattavaa vaikuttamista, joka ei ole välttämättä eriytynyt suunnitelmallisesti harjoitettavaksi opintojen organisoimiseksi.

Oli kyse sitten eriytyneestä tai eriytymättömästä opintotoiminnasta, tähän oppimisprosessiin pitää kytkeä paitsi yksityisen opiskelijan, niin myös järjestökollektiivin omaa aktiivista toimintaa.

Mielenkiintoiseksi ja haastavaksi kansainvälisyyskasvatuksen tekee sen laajuus ja vaikeus.

Vaikka maapallo supistuu, vaikka olemme entistä riippuvaisempia toisistamme, kun Eurooppa yhdentyy taloudellisesti ja kulttuurillisesti, silti näistä kysymyksistä mielikuvan luominen, tai tiedostavana jopa aktiivisena vaikuttajayksilönä tai -liikkeenä toimiminen, on hankalaa. Se on sitä laajuutensa, abstraktisuutensa 
mutta myös toiminnan tulosten arvioinnin kannalta.

Lehdistö, radio ja TV tuovat informaatiota maailmasta, välittävät uutisia tapahtumista, raportoivat taustoja ja kehityslinjoja. On tutkimuslaitoksia, mistä saa tietoa ja asiantuntemusta. Tätä kautta tapahtuu aivan normaalia aikuisten arkipäivän oppimista. Kuinka riittävää se sitten on, se on arvostuskysymys ja mitä suurimmassa määrin poliittinen kysymys.

Mitä ohuempi kerros harrastaa kansainvälisiä kysymyksiä, välittää tietoa tai päättää niistä, sitä suurempi mahdollisuus on, että objektiivisuuden suojassa esitetään sellaisia 'tosiasioita', jotka aina ovat myös arvostuksia.

Vaikka kansainvälisiä kysymyksiä monesti puetaan viileäksi ja kaikenkattavaksi neutraaliksi ja objektiiviseksi kuvaukseksi, sen taustalla ovat erilaiset arvot ja edut.

Tuskinpa kukaan epäilee, etteikö esim. Euroopan yhdentymiseen, kehitysyhteistyöhön, aseidenriisuntaan, ympäristönsuojeluun jne. liity erilaisista arvo- ja etunäkökohdista lähtevää toiminnallisuutta.

Kansalaiskasvatuksen tavoitteena olisi paitsi kontrolloida päätöksentekijöitä, niin myös luoda omista arvolähtökohdistaan käsin toisenlaista, joskus jopa vaihtoehtoista tietoa ja toimintaa.

Jos oppiminen ymmärretään muutokseksi, missä tiedot, asenteet, tunteet ja taidot kehittyvät, missä ihmisen tai kollektiivin kyky käsittää ympäröivää maailmaa paranee, tähän oppimistapahtumaan on kyettävä sisällyttämään muutamia aivan olennaisia seikkoja.

\section{Olisiko näistä ohjenuoriksi?}

TSL on kirjannut näkemyksiään oppimisesta uusiin kurssin- ja kerhonohjaajan oppaisiin. Läpikäyvänä periaatteena oppiminen nähdään opiskelijan aktiivisena henkisenä toimintana, suhtautumisena toimintaan, itse toiminnasta ja tämän toiminnan arvioinnista.

'Kurssi läpi elämän' -oppaaseen on kiteytetty neljä opintotoiminnan ohjenuoraa:

\section{Motivaatio \\ 2. Toiminnallisuus \\ 3. Havainnollisuus \\ 4. Anviointi}

Olipa sitten kyse kerho- tai kurssiopiskelusta, luentotilaisuuksista, esitelmistä tai av-ohjelmista, kulttuuriaktiviteetista tms. toiminnasta, kovin suurta osaa näistä periaatteista ei sovi jättää pois, mikäli halutaan, että tapahtuu oppimista.
Oppimisella voi tarkoittaa tässä niin yksilön, ryhmän tai jopa jonkun organisaation tietojen ja taitojen kasvamista, kykyä käsitellä ympäröivää todellisuutta ja vaikuttaa siihen. Oppiminen näkyy muutoksena, se näkyy onnistumisen tunteena, joka parhaassa tapauksessa antaa intoa yrittää vielä parempaa.

Käsittelen seuraavaksi näiden opintotoiminnan 4 ohjenuoran käyttökelpoisuutta kehitysyhteistyön valistustoiminnassa.

TSL:Ila on konkreettisia hankkeita namibialaisten ja nicaragualaisten kanssa, ja näitä hankkeita on käytetty kansalaiskasvatuksen eräänlaisina työkaluina.

Näistä kokemuksista tai esimerkeistä voi löytyä uusia ideoita ja sovellutuksia, miten aloittaa kansainvälisyyskasvatus jollakin toisella lohkolla, esim. Euroopan yhdentymisestä ja sen tulevaisuuden vaikutuksista, mikä on suotavaa, mikä ei jne. Samaa voi olla joillakin ympäristö- ja ekologiasisällöillä.

\section{MOTIVAATIO}

Suuressa osassa aikuiskasvatusta opiskelija osallistuu johonkin opintotoimintaan välittömän hyödyn vuoksi. Etenkin ay-koulutuksen sisällössä aika iso osa on eduntavoittelua jo ay-liikkeen toiminta-ajatuksen pohjalta.

Hyvä opintotapahtuma on sellainen, missä osallistuja voi kokea saaneensa eväitä ajaa esim. oman työpaikkansa työntekijöiden asioita. Järjestökoulutuksella tehostetaan mm. osaston toimintakykyä. Opiskelun tavoitteet sinällään motivoivat opiskelemaan. Siitä on hyötyä.

Yleissivistävässä ja kulttuuripitoisessa opintotoiminnassa osallistumisen motiivit ovat hieman erilaiset. Tietenkin näittenkin opintojen taustalla on hyötyminen esim. siten, että omakuva sen hetkisestä osaamisesta täsmentyy, että ymmärtää oman roolinsa ja mahdollisuutensa elää ja vaikuttaa yhteiskunnassa ja myös maailmassa, kokee myönteisenä ristiriitana senhetkisen tilanteensa suhteessa kaikkeen siihen, mitä voisi olla tai mitä voisi saada aikaan.

Poliittisessa kasvatuksessa motiivi lähtee arvo- ja etunäkökohdista. Yksilön tai ryhmän opiskelun ja toiminnan välillä on parhaassa tapauksessa kiinteä yhteys. Uusien poliittisten, tai yhteiskunnallisten arvojen ilmaantuessa, oppimisprosessissa ihminen testaa aikaisempaa tietoaan, kokemuksiaan ja toimintamallejaan, ja parhaassa tapauksessa haluaa kehittää niitä. Samalla ihmisen käsitys itsestään ja mahdollisuuksistaan yhteisössä muuttuu ja täydentyy.

Edellämainittu jaottelu on mekaaninen, eikä tällainen lokerointi anna oikeaa kuvaa motiiveista. Yhtä hyvin voi sanoa, että ay-koulutus lähtee arvonäkökohdista ja on siinä mielessä poliittista kasvatusta. 
Kun nyt on kyse kuitenkin kansainvälisyyskasvatuksesta, on syytä yrittää selvittää, miksi ihmisillä olisi kiinnostusta osallistua siihen. Ja jos sitä ei ỏle, miten tätä kiinnostusta voisi herättää.

Hyöty-motiivi sopii perin lievästi kansainvälisyyskasvatukseen lyhyellä perspektiivillä. Se voi ilmetä järjestön imagon kohottamisena, mutta yksilötasolla on parempi puhua ennemmin antamisesta. Tietenkin maailmaanlaajuisten ongelmien (asevarustelu, ekologinen uhka, kehitystä jarruttava kolmannen maailman köyhyys, blokkiajattelu jne.) ratkaiseminen hyödyttää jokaista ihmistä ja koko ihmiskuntaa, mutta tuskinpa oppimisen tai osallistumisen motiivi lähtee yksilön kokemasta hyötymotiivista.

Taustalla on arvomaailma. TSL:n kansainvälisyyskasvatuksen tehtävänä on mielestäni luoda jäsenistölle ja myös laajemmin kansalaisille tilanteita, missä voi testata omia käsityksiään, kokemuksiaan, toimintaansa ja tarjota mahdollisuus toteuttaa itseään.

Opinnollisten tilanteiden valikoiman tulisi olla laaja, jotta kyettäisiin tavoittamaan mahdollisimman suuri osa jäsenistöä. Samalla aiheet tulisi valita siten, että ne mahdollistavat jäsentää olennaisia pääkysymyksiä monimutkaisesta ja suuresta asiakokonaisuudesta.

Ydinasiat tulisi ankkuroida reaaliseen todellisuuteen ja sellaisiksi paloiksi, jotka edesauttavat oppimisprosessin ja toiminnallisuuden viriämistä. Tavoitteen realistisuus, ymmärrettävyys ja tiedottavuus merkitsevät paljon, miten voimme yrittää kohdata jäsenkuntaa kansainvälisyyskasvatuksessa.

Jos yritämme yhdellä kertaa mahduttaa kaikki mahdolliset asiat, mitä liittyy esim. kehitysmaiden tilanteeseen, kuvasta voi tulla niin laaja ja samalla pinnallinen, ettei sellaista viestiä ole ensinnäkään mahdollista ajan, palstatilan ja opetustilanteen rajoissa esittää, puhumattakaan tällaisen viestin vähäisestä kiinnostavuudesta.

Ydinkysymyksiä pitää päästä purkamaan ja laajentamaan niistä asiakokonaisuuksista, jotka ovat ymmärrettäviä, liittyvät kokemusmaailmaan ja mahdollistavat myös oman toiminnan. Sisältöjen ja tavoitteiden tulisi olla siten mitoitettuja, että ne ovat viestitettävissä eräänlaisina oppimistilanteina, jotka voitaisiin kokea kiinnostaviksi.

Käytännön projektit ovat tällaisia siltoja abstraktisuudesta konkretiaan, teoriasta todellisuuteen ja päinvastoin. On yhdentekevää väitellä, kumpi on ensin, muna vai kana, jos esim. jonkun ammattiosaston työntekijät rakentavat vapaaehtoistyönä jonkun laitteen kehitysmaihin, ja siinä ohessa ja sen jälkeen alkavat pohtia minkälaiseen tarpeeseen se menee. Jostakin on vain saatu virike, joka on synnyttänyt toimintaa ja sen yhteydessä oppimista.

Väitetään, että nuoret, naiset ja enemmän koulutusta saaneet ovat herkempiä osallistumaan kansainväliseen toimintaan. Jos näin on, voidaanko väittää samalla, että vähemmän koulutusta saaneilla ammatissa tai maataloudessa toimivalla keski-ikäisellä ja sitä vanhemmalla miehisellä sukupolvella on paatunut sosiaalinen omatunto, jolta puuttuu kyky jäsentää maailmaa? Tuskinpa.

Ennemmin voisi pohtia sitä, mitä on tehty tai jätetty tekemättä, jos tällaisiin väitteisiin on päädytty. Mikä on ollut se kieli, jolla asioista puhutaan, mitä asioita on painotettu, onko niillä mitään yhtymäkohtaa esim. siihen arkipäivän todellisuuteen, missä esim. suomalainen työntekijä elää, onko sitä osaamista ja kokemusta, jota hänellä on, voitu käyttää oppimisprosessissa, tai sitä ennen aktivoinnissa?

Kokemukset suomalaisen ay-liikkeen, ennenkaikkea liittojen toteuttamista konkreettisista projekteista ja niiden yhteydessä toteutetuista valistuskampanjoista ovat olleet myönteisiä. Mainitaan esim. metalli, rakennus, metsurit, paperi, terveydenhoitajat, kirjastonhoitajat, puutyöväki jne. Esimerkkejä on muitakin. MTK:n ja Maaseudun Sivistysliiton talonpojan talkoot Sambian projektin tueksi on ollut menestys. Kansainvälisellä Solidaarisuussäätiöllä on ollut lukuisia yhteisiä projekteja eri liittojen kanssa.

Aivan oman lukunsa ansaitsisi suomalaisten kuntien kummitoiminta. Erilaisten kunnallisten toimialojen luottamusihmiset yhdessä työntekijöiden ja hallinnon kanssa ovat kyenneet kehittämään konkreettisista hankkeistaan mitä mielenkiintoisimpia valistuskampanjoita. Koulu- ja terveystoimi, kunnossapito ja rakentaminen, neuvolat ja lastentarhat, nuoriso- ja kulttuuritoimi ovat omilla tuloksillaan osoittaneet, mitä resursseja ihmisillä on tällaisen toiminnan hyvään organisointiin.

Entistäkin vakuuttuneemmaksi motivaation olemassaolosta, tahdosta ja mahdollisuuksista toimia, tulin, kun saatoin osallistua TSL:n kutsuman nicaragualaisen köyhän kunnan pormestarin kuukauden valistusturneelle eri puolelle Suomea.

TSL:n opintojärjestöjen ihmiset loivat itse vierailuohjelmat, oli virallisluonteiset kunnan päättäjien tapaamiset, erityisvierailut kuntien toimialueilla kouluissa, terveyskeskuksissa, nuoriso- ja liikuntapuolella, kansalaisopistoissa, neuvoloissa, lastentarhoissa, jne. Keskusteltiin pienyrittäjien kanssa, käytiin tuotantolaitoksissa ja maatiloilla. Perehdyttiin metsätalouteen ja metsänistutukseen, kalatalouteen, ympäristönsuojeluun. Oli kansalaisjärjestö- ja ammattiyhdistystapaamisia. Oli esitelmiä suomalaisesta kansanvaltaisesta järjestelmästä, vaali- 
laeista jne. Tavattiin tutkimuslaitosten ja ammattiopistojen opettajia. Ja aina oli julkinen sana, lehdet ja radio mitä positiivisimmin mukana.

Kuin yhteenvetona kuukauden kiertueen kokemuksiin kyseinen nicaragualainen pormestari kysyi: "Ihmiset haluaisivat tehdä paljon maailman auttamiseksi. - Mikä heitä pidättelee?"

Yhteistä em. kampanjoille on ollut se, että ne ovat suuntautuneet suoraksi toiminnaksi. Jäsenkunnan elämän- ja työtilanne, osaaminen ja kokemus on yritetty nivoa käytännön toiminnaksi. Etäiset asiat ja erilaiset ihmiset ja kulttuurit on tuotu helpommin tunnistettaviksi osoittamalla, että pohjimmiltaan on kyse aivan samantyyppisten asioiden tai ongelmien ratkaisemisesta, kuin mitä meillä on toteutettu. Monesti tällä tavalla kerätty kokemus, kehittelytyö ja toteutus on luonut jopa jotakin uutta toteutusta, missä on voitu ottaa huomioon kehitysvaiheessa olevat erot. Koska motiivit ovat erilaiset verrattuna esim. konsultti- tai yritystoimintaan, kansalaisjärjestöt projekteineen ovat saattaneet löytää sellaisia ratkaisu- ja toteutusmalleja, jotka ovat nostaneet koko kehitysyhteistyön tasoa. Pienellä rahalla on voitu toteuttaa suhteessa onnistuneempia hankkeita, kuin mitä suurella rahalla yritysten tai viranomaisten toimesta.

Yhtenä tavoitteena tai motiivina on vaikuttaminen kansalaismielipiteeseen ja valtion tai valtioiden harjoittamaan politiikkaan. Julkilausumat ja pontevat puheet tietenkin auttavat, mutta jos haluaa varmistaa, että jotakin tapahtuu, silloin toiminnassa on oltava mukana kaikilla tasoilla.

Kansalaismielipiteen, toiminnan ja tulosten on oltava sitä luokkaa, että rooli suhteessa päättäjiin on tasa-arvoinen. Sen saavuttamiseksi yleensä tarvitaan näyttöjä. Puheet ja julkituodut lausumat toki otetaan huomioon, mutta millä tavalla, jollei niiden tueksi ole mitään osoitettavaa.

Siksi kansalaisjärjestön tai poliittisen liikkeen on toimittava kansainvälisyyskysymyksissä pitemmällä aikavälillä. Toimintajänne on valitettavan pitkä, jos halutaan tuloksia.

Järjestöelämän suvantovaiheiden yli on silti kuljettava, ja siksi toiminta on sidottava johonkin kestävään tavoitteeseen. Niitä ovat juuri käytännön hankkeet ja niissä onnistuminen.

Tällainen onnistuminen merkitsee oppimiselle ja uuden yrittämiselle paljon. Olla tavalla tai toisella mukana käytännön kehitysyhteistyössä, miettiä miten asiat ovat meillä, miten siellä, miten voisi auttaa parhaiten, tutkia ja toimia. Tapa ei ole kovin kaukana tutkivasta opintotoiminnasta, missä ei ole kaikki aineisto valmiina, vaan pitää perehtyä taustoihin, koko- naisuuteen, mutta myös erilaisiin yksityiskohtiin.

Jos tavoitteena on kansainvälisyyskasvatus kansalaiskasvatuksena, ei ole mielekästä väitellä, tapahtuuko oppimisprosessi yksityisestä yleiseen, vain yleisestä kuvauksesta yksityiseen. Joillekin sopii ensimmäinen, toisille taasen jälkimmäinen malli.

\section{TOIMINNALLISUUS}

Kansainvälisyyden opinnollisissa tilanteissa, kursseilla, kerhoissa, luentotilaisuuksissa, tiedotteissa, kampanjoissa, kulttuuritapahtumissa keskustellaan niin yleisistä kuin yksityisistä asioista.

Oppimisprosessia ajatellen olennaista on, että tilanteessa on toiminnallisuutta, yksilöllistä tai ryhmän kesken. On erilaisia tehtäviä tai kysymyksiä, jotka pyritään ratkaisemaan. Näin osallistujat voivat arvioida omaa osaamistaan, tietävät lähtötason ja voivat soveltaa ja kokeilla uutta tietoainesta. Ryhmässä tällainen tehtävä parhaassa tapauksessa rohkaisee osallistumaan, motivoi ja suuntaa erilaisista mielipiteistä huolimatta johonkin yhteiseen päämäärään.

Tehtävän tulee olla mielekäs, tavoitteen realistinen ja resurssien rajoissa, ja että sillä on merkitystä. Simulointi- tai kuivaharjoittelu jonkin tehtävän kimpussa, joka ei täytä em. kriteerejä turhauttaa.

Ihminen, joka osallistuu kansainvälisyyskasvatukseen etsii opinnollisesta tapahtumasta paitsi lisätietoja myös ideoita tai valmiuksia omaan osallistumiseensa. Kiinnostus voi suuntautua mihin tahansa. Joku haluaa alkaa opiskella maailmanhistoriaa, kansainvälistä politiikkaa, talouspolitiikkaa. Joku kiinnostuu kirjallisuudesta, musiikista, elokuvasta, kuvataiteesta, uskonnosta tai yleensä vieraasta kulttuurista. Monelle se voi olla virike alkaa opiskella vierasta kieltä ja matkustaa lomalle ulkomaille, eikä pelkästään ruskettumaan. Moni miettii mahdollisuuksiaan lähteä kehitysmaihin töihin, opiskelija saattaa alkaa harkita opiskelua ulkomailla ja sen taloudellisia mahdollisuuksia.

Jotakin saattaa alkaa kiinnostaa kehitysyhteistyöhön osallistuminen. Hän voi työskennellä sellaisessa toimessa, missä työtovereiden tai kolleegoiden kanssa voi kehitellä omaa osaamistaan sivuavia yhteistyöhankkeita, neuvotella työnantajien kanssa joittenkin materiaalien toimittamisesta jne.

TSL:n tulisi tarjota sellaisia kanavia, missä ihmiset, yksilöinä tai ryhmänä voisivat toteuttaa omia ideoitaan ja halujaan. Meillä tulisi olla toiminnallinen alue, joka rohkaisisi opiskeluun ja luovaan toimintaan. Osallistujien ei 
tarvitsisi tuhlata resurssejaan byrokraattiseen hallinnointiin eikä yhteyskanavien rakentamiseen, vaan he voisivat keskittää voimansa itse toimintaan.

TSL:n kehitysyhteistyöprojektit ovat tällaisia kanavia. Projektien tavoitteiden sisälle, mutta myös oheen voi kehitellä moninaista toimintaa. Hankkeiden päätavoitteiden toteuttamiseen ei ole vaikea osallistua, niihin voi tulla ja antaa oman panoksensa. Mikään ei estä tekemästä muutakin. Kanava on auki, hallintorutiinit ja byrokratian asiat hoituvat projektien siivellä. Mikään ei estä toteuttamasta vaikkapa aikuisopiskeluun liittyvää hanketta tai kulttuuritoiminnan projektia.

Esimerkkejä piiri- tai paikallistason aktiviteetista on erilaisia, joissakin ammattiosastoissa on tehty talkoovoimin koneita ja laitteita, TSL:n piirit ovat järjestäneet kulttuuritapahtumia, keränneet erilaisia tavaroita, toteuttaneet omia hankkeitaan, järjestäneet kursseja ja tiedotustilaisuuksia, valistaneet ja kampanjoineet ja uusia ihmisiä on tullut TSL:n toimintaan. On syntynyt ystävyyskouluja ja kehitelty muutenkin kuntatason kansainvälistä toimintaa.

Ensimmäinen työprikaati työskenteli viime kesänä 4-6 viikon ajan TSL:n projekteissa Nicaraguassa. Nyt nämä 16 prikaatilaista ovat aloittaneet omilla kotipaikkakunnillaan hyvin moninaista kehitysyhteistyötoimintaa.

Kehitysyhteistyökumppani ei pane pahakseen, jos sikäläisille ihmisille lähetetään vaatteita, kenkiä ja kattiloita, tai jos nuorten vapaaajanviettoon hankitaan urheiluvälineitä, discolaitteita ja soittimia, tai jos terveyskeskuksiin kerätään kalustoa, leikkausvälineitä ja lääkkeitä, tai jos otetaan nimikkokouluja, joille toimitetaan kynistä ja paperista lähtien erilaista oppi- ja av-materiaalia, tai jos jälleenrakentamiseen suomalaiset kunnostavat ja lähettävät käytettyjä työkalujaan ja vanhoja oppikirjojaan.

Kun hätä on suuri, tällaista apua ei ole syytä vähätellä. Kyynisyys ja nirsoilu on kuin asettautumista reaalisen todellisuuden yläpuolelle.

\section{HAVAINNOLLISUUS}

Kansainvälisyyskasvatuksen aihevalikoima on suuri, yksityiskohdat saattavat peittää asioiden ytimen ja olemuksen. Opiskelijan tulisi kuitenkin pystyä käsittelemään ja ymmärtämään sitä aineistoa, jonka kanssa hän työskentelee, jotta syntyisi jäsentynyt kokonaisuus ja selkeä kuva asiasta.

Yksi ja aivan olennainen seikka kansainvälisyyskasvatuksessa on sen tavoite, - minkälaisten asioiden hallintaan pyritään ja mikä on tämä punainen lanka. Kaikkea ei voi ottaa tavoitteeksi yhdellä kertaa, mutta se mitä käsitellään, tulisi olla jäsentynyt ja ehjä kokonaisuus asioiden ytimestä.
TSL on tuottanut yhdessä Kehitysmaainstituutin kanssa luennoitsijoita varten monipuolisen ja laajan kalvo- ja alustuskansion, opintokerhomateriaalin, erilaista audiovisuaalista aineistoa filmeistä ja diaohjelmista valokuvanäyttelyihin. Paraikaa on painossa yhteispohjoismainen ABF-oppikirja kansainvälisistä kysymyksistä.

Jo pelkästään TSL:n omin voimin toimittamaa perusmateriaalia on kohtalaisesti. Täydennystä voi saada muilta järjestöiltä.

Asioiden olemuksen ja ytimen esittäminen on opinnollista materiaalia, toinen asia on, kuinka runsaasti sitä käytetään, ja missä sitä käytetään. Onko esimerkiksi riittävästi tarjolla sellaisia opinnollisia tilanteita, kursseja, kerhoja, luentotilaisuuksia, missä näitä materiaaleja käytetään.

Mutta mitä työkaluja jäisi kansainvälisyyskasvatukseen, jos projektitoiminta lopetettaisiin? Siirryttäisiin abstraktitasolle ja tyhjiöön simuloimaan teoreettisilla kuvilla ja yleistyksillä?

Projektit ovat toimineet tähän asti kansainvälisyyskasvatuksen ydinasioiden ja keskeisen olemuksen havainnollistajana. Niillä on pelkistetty, luonnonmukaistettu ja rikastettu asioiden käsittelyä.

Mikä on se tapa, jolla asiat voitaisiin esittää mahdollisimman aidossa ja ymmärrettävässä muodossa, jos ei ole enää erimerkkejä, ei todellisuutta, ei suoraa kommunikaatiota, jota voi esittää kokemuksina, valokuvina, filmeinä, kertomuksina, haastatteluina. Miten voi kertoa asioiden todellisesta tilanteesta, miten ihmiset elävät, minkälaisia ovat heidän ongelmansa, mitkä ovat ne taustatekijät, jotka vaikuttavat maan tilanteeseen, minkälaisia ulospääsymahdollisuuksia heillä on, ellei ole muuta kuin abstraktio, tyhjä teoreettinen kuvio.

Miten voit esitellä asioita monipuolisesti ja elävöittäen, jos esimerkit, vertaukset, kuvat, äänet, musiikki, värit, - - koko se elämän todellisuus putoaa pois oppimistilanteesta.

Tällaisessa oppimistilanteessa ei voi enää ottaa toiminnallisia uusia tavoitteita. Mistä keksiä toteuttamiskelpoiset ideat, ellei ole autenttista ja paikkansapitävää tietoa, mitä voisi tehdä.

\section{ARVIOINTI}

Oppimista on kuvattu muun inhimillisen toiminnan tavoin siten, että se muodostuu kolmesta erillisestä vaiheesta: - suuntautumisesta toimintaan, itse toiminnasta ja sen arvioinnista.

Miten sitten voisi arvioida laajasti ottaen kansainvälisyyskasvatuksen onnistumista TSL:ssa. Minkälaisia mittareita siinä voisi käyt- 
tää. Kenen näkökulmasta tarkastellaan tätä työtä. Mitä on saatu aikaan ja mitä ei.

Ensinnäkin kansainvälisyyskasvatuksen pääpaino on ollut kehitykseen liittyvässä ongelmatiikassa.

Kun yhteistyökumppaneina ovat namibialaiset ja nicaragualaiset, projektien kautta välittyy paitsi kolmannen maailman yleinen tilanne, myös siirtomaapolitiikan ja suurvaltapolitiikan historia ja nykypäivä. Molemmissa maissa itsenäisyyden ja riippumattomuuden saavuttamiseksi käydään tai on käyty sotaa.

Namibian tapauksessa kysymyksessä on lisäksi perustavaa laatua olevat ihmisoikeudet ja apartheid-politiikka Etelä-Afrikassa. Geopoliittisesti ja taloudellisesti Väli-Amerikka ja eteläisen Afrikan maat muodostavat omat erityisalueensa.

TSL:n projektit ovat ns. tuotannollisia ja koulutuksellisia projekteja. Tiilitehtaiden, sahojen, puusepänverstaiden ja kuljetuskaluston hankinta on mahdollistanut kotimaassa runsaasti vapaaehtoistyötä ja erilaisten ihmisten osallistumista hankkeen suunnitteluun ja toteutukseen.

Yhteistyöprojektit ovat luoneet uutta tuotantoa, sosiaalista rakentamista, ammattitaitoa sekä pysyviä työpaikkoja kohdemaahan. Hankkeista on asiallinen kuva niin kohdemaissa, suomalaisten viranomaisten kuin kansalaisjärjestöjenkin keskuudessa.

Pitempiaikaisista projekteista ja niissä työskentelystä paikan päällä on saatu kulttuurituntemusta ja uutta informaatiota kehitysmaan olosuhteista.

Tätä paikanpäällä hankittua asiantuntemusta on voitu hyödyntää uusien hankkeiden suunnittelussa ja kohdentamisessa. Tämä koskee paitsi TSL:n paikallistason ihmisten kehittämissä toiminnoissa, myös muiden järjestöjen ja valtion laitosten suunnittelemissa hankkeissa.
TSL on voinut työskennellä myös muiden järjestöjen ja nicaragualaisen osapuolen asioiden välittäjänä. Entistä enemmän tulee tällä hetkellä erityisiä pyyntöjä Nicaraguasta välittää erilaisia projektiesityksiä mahdollisille suomalaisille toteuttajille. Viimeisimmät koskivat kalataloutta ja metsitysohjelmia luonnonkatastrofialueille.

Unescon kansainvälisyyskasvatuksen kaikkia suosituksia ja alateemoja emme ole kyenneet kuin pinnallisesti käsittelemään. Esim. kehitysmaiden oma aseidenriisunta, sotien lopettaminen, militaaristen rakenteiden purkaminen, ihmisoikeuksien puolustaminen ja amnestia, siirtyminen rauhaan ja demokraattisesti hallittuun yhteiskuntajärjestelmään ovat tietenkin olleet kehitysyhteistyössä sisällöllisesti mukana Namibian ja Nicaraguan kohdalla, mutta vain välillisesti.

Aikuiskavatukseen ja yleensä koulutukseen, kulttuuritoimintaan, sosiaalisiin ohjelmiin, tasa-arvokysymyksiin, ympäristö- ja ekologiakysymyksiin sekä elintarvikkeiden omavaraisuuden turvaamiseen liittyviä ohjelmaesityksiä olisi runsaasti valmiina projektiesityksinä.

Euroopan yhdentyminen, sosialististen maiden uudistusprosessiin, kansainväliseen kulttuuriyhteistyöhön, aseidenriisuntaan, ympäristökysymyksiin ja viestintäpolitiikkaan jne. ei ole liiennyt voimavaroja.

Kansalaisjärjestöjen kehitysyhteistyön valtionsäädökset 40 \%:n omavastuuosuuksista ovat valitettavasti niin korkeat, ettei TSL:n tapaisen sivistysjärjestön resurssit yllä kovin suuriin toimintojen laajennuksiin. Sama koskee TSL:n kansainvälisyyskasvatuksen kotimaan päätä. Kouluhallituksessa on useita vuosia jatkunut nurja suhtautuminen uusien opetusvakanssien perustamiseen. 


\section{AIKUISKASVATUS \\ The Finnish Joumal of Adult Education \\ Vol. 9, 3/89 \\ ISSN 0358-6197 \\ Summary}

Ylinen, Seppo 1989. Intemational education as a part of adult education - experiences and potential for development. Aikuiskasvatus 9,3 .

The article deals with the reasons for providing intemational education in the world of today and which matters should be taken into account when organising it. The starting point for the treatment of this subject is the development cooperation practised by the Workers' Educational Association and the experiences gained from it. The author is of the opinion that students must be provided opportunities for testing their own concepts in conjunction with intemational education and that they should also be given opportunities for actually participating in intemational cooperation. Special attention should be paid to motivation, activities, illustrativeness and the evaluation of action taken. The problem usually faced by citizens' organisations when they arrange intemational education is the lack of resources. 